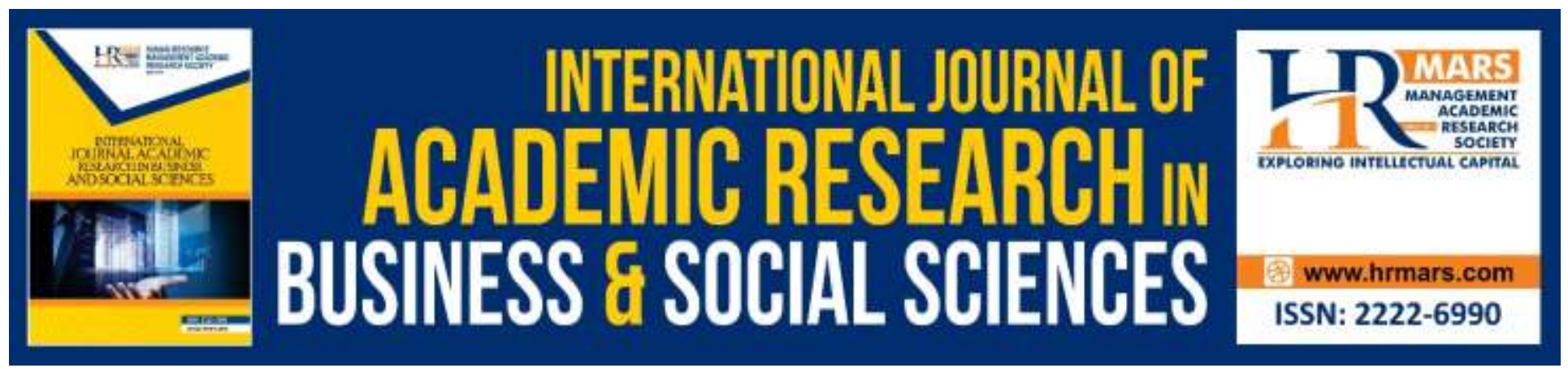

\title{
Financial Education as Moderating Influence in Prudent Financial Management Practices among Malaysian Youth
}

\author{
Mohd Zamri Abu Bakar, Saridan Abu Bakar, Suffian Hadi Ayub
}

To Link this Article: http://dx.doi.org/10.6007/IJARBSS/v10-i2/6856

DOI:10.6007/IJARBSS/v10-i2/6856

Received: 12 January 2020, Revised: 25 January 2020, Accepted: 30 January 2020

Published Online: 10 February 2020

In-Text Citation: (Bakar et al., 2020)

To Cite this Article: Bakar, M. Z. A., Bakar, S. A., \& Ayub, S. H. (2020). Financial Education as Moderating Influence in Prudent Financial Management Practices among Malaysian Youth. International Journal of Academic Research in Business and Social Sciences, 10(2), 1-11.

Copyright: (c) 2020 The Author(s)

Published by Human Resource Management Academic Research Society (www.hrmars.com)

This article is published under the Creative Commons Attribution (CC BY 4.0) license. Anyone may reproduce, distribute, translate and create derivative works of this article (for both commercial and non-commercial purposes), subject to full attribution to the original publication and authors. The full terms of this license may be seen at: $\underline{\text { http://creativecommons.org/licences/by/4.0/legalcode }}$

$$
\text { Vol. 10, No. 2, 2020, Pg. } 1 \text { - } 11
$$

Full Terms \& Conditions of access and use can be found at http://hrmars.com/index.php/pages/detail/publication-ethics 


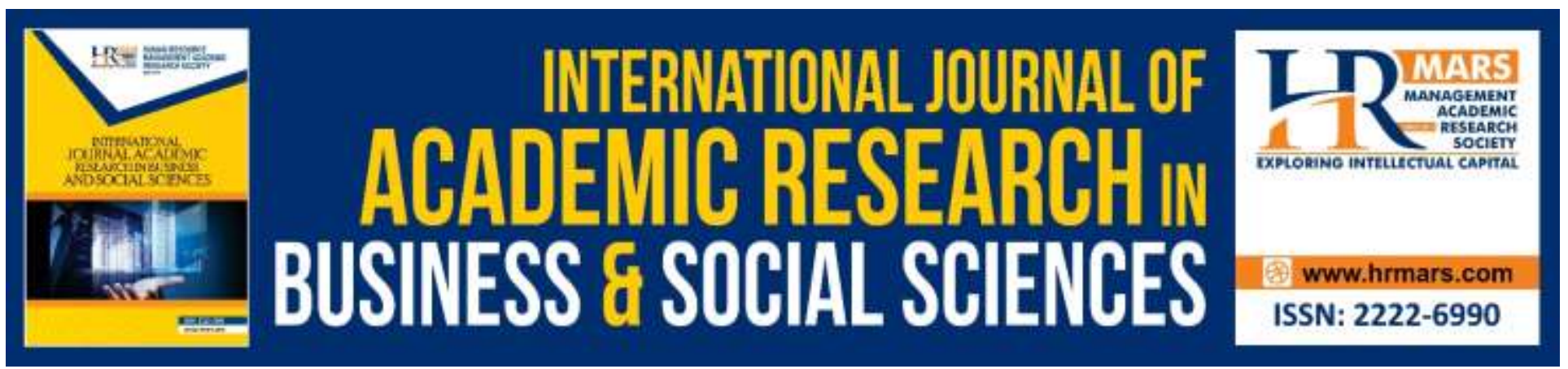

\title{
Financial Education as Moderating Influence in Prudent Financial Management Practices among Malaysian Youth
}

\author{
Mohd Zamri Abu Bakar ${ }^{\mathrm{a}}$, Saridan Abu Bakarb, Suffian Hadi Ayubc \\ ${ }^{a}, b$ Institute of Business Excellence, Faculty of Business Management, Universiti Teknologi Mara, \\ Malaysia, ' Department of Communication, School of Arts, Sunway University
}

\begin{abstract}
Studies have indicated that the key contributors to heavy financial debt among youth are global economic situation with uncertainty of economic growth, wide access of financial product, and sophistication financial environment. Additionally, the market regards youth as primary lucrative market and this has led the youth to fall into poor financial practices and widely exposed to bankruptcy. The inability for youth to become financially sustainable in manoeuvring their expenditure and savings further cemented the notion that youth are lacking in financial knowledge which lead to indecisive financial decision. The study aims to investigate the influence of financial education (FE) as a moderator to financial attitudes (FA), parental financial socialisation (PFS), and financial literacy (FL) to ensure the successfulness of Prudent Financial Management Practices (PFMP) among Malaysian youth. This study employed self-administered questionnaires which were adopted from previous studies and distributed to 140 youth in Malaysia which were later analysed using SPSS to address the research objectives. The result indicated that FE is not significant moderator to FA, PFS, and FL in determining the PFMP among youth in Malaysia. The finding further highlighted that PFMP among youth are the result of shared accountability from various stakeholders such as parents, policy makers, and financial institution.
\end{abstract}

Keywords: Education, Youth, Finance, Knowledge, Behaviour

\section{Introduction}

The business world is witnessing a rapid change nowadays with the proliferation of the technology that aims at providing easefulness to the consumer. These supposedly fast and easy access have allowed the consumer to increase their spending at their comfort. Subsequently, consumers are able to gauge the spending habit without much thought of the consequences thereafter; primarily in the aspect of financial health. Hauff, Carlander, Gärling and Nicoloni (2020) further stated that in today's era of consumerism, the financial environment is more complex and requires individuals to possess higher level of financial knowledge instead of just basic financial understanding. The financial health 
of individuals is paramount as it determine the likelihood of these people in order to survive the challenging economic environment they live in. Without sufficient knowledge and awareness on financial related matters, individuals could easily fall victim in today's financial systems and its complexity. Aydilek and Aydilek (2019) stated that insufficient financial knowledge and poor financial skills have caused many individuals to be trapped in serious financial problems because they are unable to make suboptimal financial decision. Meanwhile Liu and Tsai, (2010); Robert and Jones, (2001); Suwanaphan, (2013); Zaini, Masrek, Sani \& Anwar (2018); Moissidou (2013); Pernamasari (2018) reiterated that its complexity also posed a great challenge for individuals and households in the financial resources management efficiently compared with what have been experienced by the previous generations.

In Malaysia, Bank Negara Malaysia (BNM) reported that household debts were recorded at 89.1\% in 2015 compared with 76.1\% in 2011; this has placed Malaysia among the top countries with highest household debts in the Asian region. The composition of household debts ballooned with housing loans comprising the largest portion (56.5\%) followed by car loans (20.5\%), personal loans (8.3\%), credit cards (5\%), securities (7.8\%) and others (2.4\%). This has trapped many individuals into indebtedness. These astounding facts and figures have raised concerns as it reflect poor financial knowledge, insufficient financial skills, lack of financial awareness and the prevalence of financial mismanagement among Malaysians. Since youth in Malaysia made up for more than $40 \%$ of Malaysian populations, any issues related to this demographic group must not be neglected by all stakeholders especially when it concerns the financial health and status. Additionally, Economic Planning Unit (2016); Malaysian Youth Index (2015) touted youth as the backbone to the country's prosperity and nation building. Such statement clearly provide a profound importance to the government's plan in ensuring youth are well taken care of through various programmes and implementation through ministries such as Ministry of Youth and Sports, Ministry of Finance, and Ministry of Domestic Trade, Co-Operation and Consumerism.

Nevertheless, studies has shown that youth are prone to spend recklessly and have very little regards on effective monetary expenditure. This demographic group also has very little or zero knowledge pertaining to the aspects of sound financial management. Studies by Chen and Volpe (1998); Förster, Happ, and Walstad (2019) revealed that young generation is synonymous with lack of knowledge, inexperience in money management and possessing low skills in managing their personal finance effectively. Further to that, Loke (2016) also cautioned that youth aged 18 to 24 years old is the largest age group living beyond their means and living in indebtedness.

Topped with easy access of numerous sites and apps in providing easy and fast access to spend, youth seem to be the easy target for the market to engage in spending their income. A study by Hoeve, Stamps, Zouwen, Vergeer, Jurrius, and Asscher, (2014) revealed that easy access to credit, deregulation in the financial world, borderless transaction, personal credit cards, debit cards and other factors have trapped many youths making them involved in reckless spending and compulsive buying. Evidently, Koen, Asada, Nixon, Rahuman, and Arif, (2017) echoed that the government aspirations is meaningless if Malaysian youth are facing great challenges in managing their financial resource effectively.

Malaysia Department of Insolvency (MDI) in its report highlighted an alarming statistics whereby between 2010 and 2015, 53\% of 101,537 Malaysian individuals to be declared with personal 
bankruptcy are youth aged below 40 year. Similarly, Malaysia Financial Planning Council Malaysia (MFPC) resonated the statistics with further revelation that these 22,663 bankrupt youth are attributed to poor financial planning. Latest statistics from Agensi Kaunseling dan Pengurusan Kredit (AKPK) revealed that between January 2017 and August 2017, the number of youth seeking assistance from the agency has surpassed 3400 cases, which was the total number of cases for entire year of 2016 (Anand \& Kumar, 2017). This issue calls for comprehensive attention from policy makers, educators, financial institution and government alike. Brown, Grigsby, van der Klaauw, Wen, and Zafar (2015) recommended that the best way for youth to avoid bankruptcy is to prudently manage their financial habit. Evidence has shown that FA, PFS and FL have strong association with PFMP (Falahati \& Paim, 2012; Fernandes, Netemeyer, \& Lynch, 2014; Kimiyagahlam, Safari, \& Mansori, 2019).

Financial attitude (FA) for the purpose of this study is referred to the belief and feeling on financial matters that shape an individual's action towards prudent financial management practices. When describing belief and feeling as predictor, it directly construed to individual ability to behave consistently upon exercising their financial obligation. This operational definition echoed with Furnham, Wilson, and Telford, (2012) in their study where FA was described as a person's state of mind, belief and assessment related to personal finance matters. This could also be associated in elucidating correlational relationships between different predictor that guide, shape and influence individual's behaviour intention towards financial health. Meanwhile parental financial socialization (PFS) is a stage where knowledge, skills, behaviour and attitudes on financial matters are acquired and transmitted from parents that influence behaviour towards PFMP. Baumrind, (1980); Grohman, Kouwenberg, and Menkhoff, (2015) stated that PFS is a development stage where individuals acquire and develop their own skills, perceptions and beliefs that influence financial characteristic of the individual. These attributes reflect aptly that financial practices, habits acquired and formed from parents during early stage of life will be imitated and further continued in the next stage in life.

The third variables employed in this study is financial literacy (FL) where the operational characterisation has been framed to the idea of an individual's understanding and application of knowledge skills which facilitate them when making financial decision effectively. Luksander, Béres, Huzdik, and Németh (2014) stated that financial literacy as knowledge in the field of finance, ability to process financial information and to make correct financial decisions. Eventually, FL is paramount in today's society especially to youth because these acquired knowledge will mobilise and enforce them to manage personal wealth efficiently and increased financial competence. Financial education (FE) is the delivery or transferrable knowledge to guide and support youth towards prudent financial management practices. Standard definition used by Organisation for Economic Co-operation Development (OECD) (2012) defined FE as the process by which financial consumers or investors improve their understanding on financial products, concepts and risks through information, develop skills, to make informed choices and to take other effective actions to improve their financial wellbeing. This very well means that FE provide a holistic assistance to individual in deciding and further improving their financial behaviour due to the fact that FE equips this demographic group with skills, tools, knowledge and information on effective financial management resources.

When discussing prudent financial management practices (PFMP), Titman, Keown, \& Martin (2017) conceptualised it as a process which concentrate on the creation of value or wealth that 
requires critical financial judgement among individuals or households. In relation to that, Winterich and Nenkov (2015) also echoed that PFMP has the potential to guide and motivate individuals to using the best financial practices which eventually could avoid any undesirable financial behaviour. Contextually, prudence in financial management is associated with disciplined financial behaviour because it helps in managing financial resources and self-control over financial situation. Within the context of this study, PFMP is a discipline that emphasis on behaviour in exercising and managing financial resources effectively.

This paper aligned the perspective of FA, PFS, FL, and FE as interrelated with FE acting as intervener to the remaining three variables. As a result to strict adherence of these variables, PFMP is expected to be catalysed for a disciplined behaviour in exercising and managing financial resources effectively. Pham, Yap, and Dowling (2012) added that it can guide and motivate individuals to engage in using the best financial practices and in avoiding any undesirable financial behaviour.

Theory of Planned Behaviour (TPB) refers to individual's attitude toward behaviour, subjective norms, and perceived behavioural control and when combined, it will shape an individual's behavioural intentions (Ajzen, 1991). In the context of this study, TPB is used to examine whether FE has a moderating effect on the relationship of FA, PFS and FL with PFMP. The importance of FA, in reinforcing social norms through $\mathrm{PFS}$, enhances perceived behavioural control through $\mathrm{FL}$ and that intervention of FE is vital in determining behaviour intention of adopting PFMP.

The theoretical framework based on TPB for this study as follow:

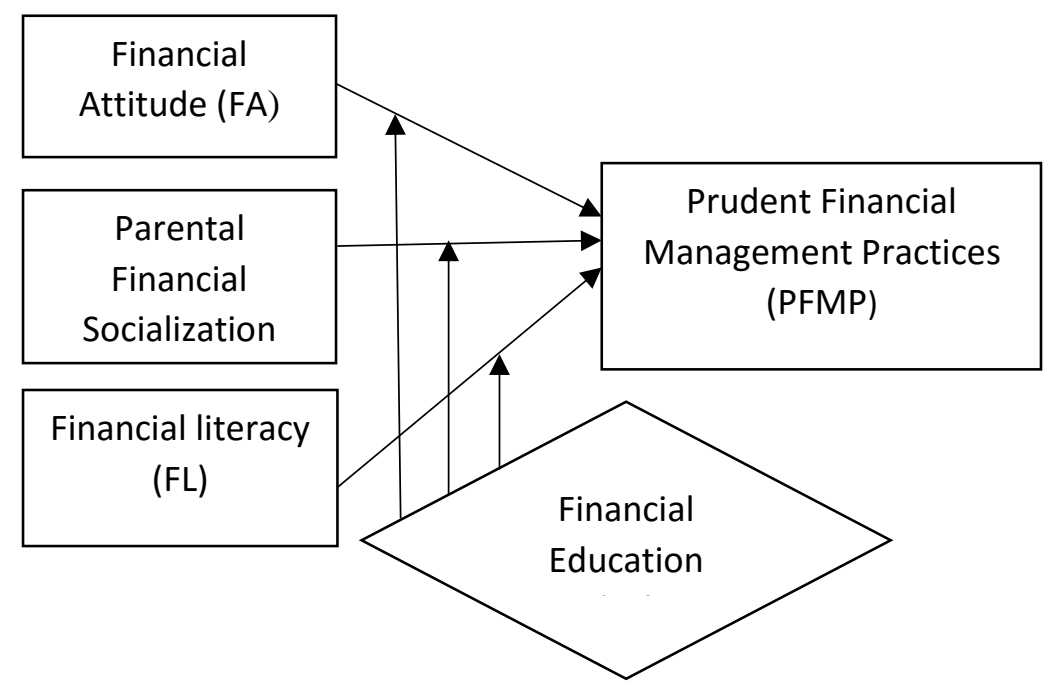

Figure 1. The theoretical model

\section{Methodology}

The quantitative approach was used through the distribution of self-administered questionnaire in the data collection. A total of 140 university students from Malaysian Institute of Aviation Technology, Universiti Kuala Lumpur (UniKL MIAT) were involved in this study and have enrolled to Personal Financial Management subject (MPU3482). 
The National Youth Development Policy of Malaysia defines youth as people aged between 15 and 40 years. It stipulates further that the main focus of youth development programmes and activities in the country should be young people aged 18 to 25 years (Economic and Social Commission for Asia and the Pacific [ESCAP], (2002). For the purpose of this study, the selected age range was between 18 to 25 years, considering the respondents are university students. Meanwhile, the measurement of variables (FA, PFS, FL, and FE) were adopted from previous study conducted by various researchers in PFMP areas.

FA was measured by ten statements taken from the study by Potrich, Viera, Coronel and Filho (2015) which examined the financial literacy in Southern Brazil: Modeling and invariance between genders whereby the questions adopted in the study focused at the component of the financial attitude of the respondents. PFS was measured through four statements in the questionnaire and it was adopted from the study by Shim, Barber, Card, Xiao and Serido (2010). Their study focused at the financial socialization of young adults, the role of family, work, and education.

FL was adopted from the study by Hira, and Loibl (2005) which looked at understanding the impact of employer provided financial education on the workplace satisfaction and represented with four statements in the questionnaire. Meanwhile FE were represented five statements in the questionnaire and was adopted from the study by Perry and Morris (2005) which investigated the role of self-perception, knowledge, and income in explaining consumer financial behavior. Finally, the ten statements to represent PFMP were adopted from Joo and Grable (2004) which conducted a study on exploratory framework of the determinants of financial satisfaction.

All of these variable were measured based on five-point Likert scale which; 1 for "strongly disagree" to 5 for "strongly agree. For analysis of the data, the research employed multiple regression as a main method to analyse the objective. Further analysis on the second layer of the research was done to determine the interaction of the variables between moderator and independent variables.

\section{Results \& Discussion}

Table 1 presents the summary of two models of PFMP that are expected to be influenced by the independent variables factors such as FA, PFS and FL. The researchers have identified the extent of the financial education which serves as the moderating factor between the relationships of independent variables and dependent variable. Model 1 shows that 14.4 percent of the factors influenced PFMP $(p=0.000, b=0.144)$. This highlights that about 14.4 percent of the variant changed in the model. Also, among the significant factors that have influenced PFMP are financial education $(p=0.00, b=0.167)$ and financial literacy $(p=0.00, b=0.257)$.

Model 1 illustrates that FE is insignificant since it gave no impact and without any interaction between variables. When analysing the FE as moderating variable, the result also showed that $\mathrm{FL}$ provided more dominant effect compared to FE. In this context, the research direction must take into consideration that $\mathrm{FL}$ for this research attempted to probe into the behavioural effect as a result to cognitive accord, therefore will significantly influence PFMP. This result concurred with the study conducted by Fernandes, Lynch Jr and Netermeyer, (2014); Hastings, Madrian and Skimmyhorn (2013) where it was concluded that financial education has limited or no ability to influence future financial behaviours. Additionally, Model 2 was developed to analyse the role of moderator factor (FE) that possibly influenced the relationship between FL, FA and PFS towards PFMP. The result also 
shows that the increase in variation explained by the addition of the interaction term (moderator). The change in $R^{2}$ is reported as 10 percent $(0.010 \times 100)$. However the model is not significant $\left(p=0.660, R^{2}=0.154\right)$. This finding indicated that $F E$ is not a moderator for the relationships between FL, FA and PFS towards PFMP. Model 2 also highlighted that the analysis was conducted to determine whether FE served as moderator or otherwise. The result showed that FE not a suitable moderator since it is not significant. Despite numerous literature reviews stated that FE is significant in determining PFMP, it is however may not be the case in Malaysia context. The fact that Malaysia education landscape is very much different from other countries, it could be one of the contributing factor to the findings.

This means that the FE subject is not taught specifically at school level even though its elements and contents are embedded in other subject at school. The same goes at university level whereby finance, business, and economics major students are at advantage as opposed to those taking other major such as engineering, language, or technical programme (Chen, \& Volpe,1998; Falahati, \& Paim, 2012; Grimes, Rogers,\& Smith, 2010). When FE is made compulsory subject to ensure graduation, students' perception of it might skew towards fulfilling the graduation requirement rather than attainment of knowledge which leads to a better consensus in PFMP and its practicality in real life.

Table 1 : Regression Analysis on Moderator Variable

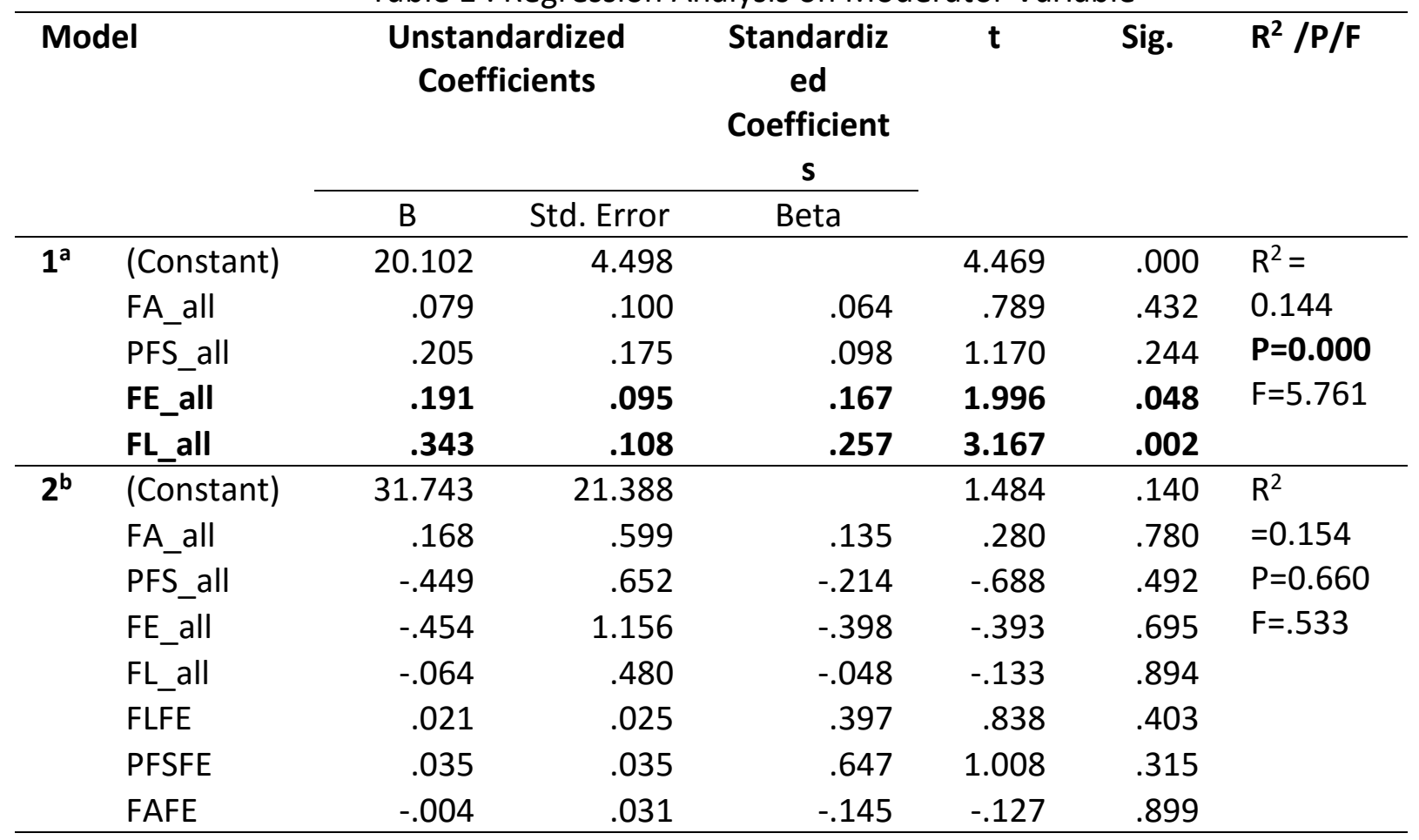

a. Dependent Variable: prudent financial management practices PFMP_all

a. Predictors: (Constant), financial literacy ( $F L) \_a l l$, financial attitude(FA)_all, parental financial socialization(PFS)_all, financial education(FE)_all 
b. Predictors: (Constant), financial literacy(FL)_all, financial attitude (FA)_all, parental financial socialization (PFS)_all, financial education (FE)_all, financial literacy financial education (FLFE), parental financial socialization (PFSFE), financial attitude financial education (FAFE)

\section{Conclusion}

Finding of this study corroborate theory of planned behaviour (TPB), which is underlying theory of this study. The study provides clear understanding of the moderating effect of FE on the relationship with FA, PFS and FL with behaviour intention, PFMP. The factor that determine the applicability of FE as moderating variable to ensure successful PFMP calls for a strict adherence to holistic comprehension of FA, PFS and FL. This study reveals profound impact on the issue rising occurrences of adverse financial behaviour among youth in Malaysia. The study proved that FA, PSF and FL significantly predicted youth financial behaviours. At the same time, the strong relationship showed that the important of FA, PFS and FL in determining youth's financial behaviour. The initiatives towards offering FE is based on fact that FE can provide financial knowledge, improved skills and play as intervention to improve youth financial behaviour. Expected outcome from the introduction of FE that it will benefit the participants into practising good money management throughout life (Bruhn, Ibarra, \& McKenzie, 2014). The effort to introduce and promote FE as an intervention tool did not show positive result to improve financial behaviour and outcomes. Even though, many expected that FE is the best intervention tool to improve financial illiteracy, the result of the study showed contradictory evidence to the findings of previous studies.

FE in our education system may not be effective and short of the quality to improve financial behaviour of youth. Thus, the result can assist respective stakeholders such as policy makers, educators, financial institutions to use the finding to re-evaluate the programmes' effectiveness and to look into the programmes' shortcomings. It is important that all FE contents cover the elements and concepts applicable and related to real financial life of youth. Stakeholders such as parents, financial institutions, educators and governing bodies must collectively spearhead the PFMP agenda across the population landscape. Additionally, stakeholders too must equip themselves with the appropriate skills in shaping youth's future and their financial health. The accessibility and content of FE must be made available to avoid confusion and misinformation due to the abundant of unverified information which could lethally affect FL due to lack of FA (OECD, 2016). Ultimately, the governing bodies such as relevant ministries and agencies, private sectors and non-government organisations are responsible to ensure the message transmit through the financial campaigns and programmes will reach and influence youth. Nevertheless, the findings provide sufficient evidence to indicate challenges facing by the country and further caution its stakeholders to revisit and evaluate the effectiveness of FE within the context of Malaysia education landscape.

\section{References}

Ajzen, I. (1991). The theory of planned behavior. Organizational behavior and human decision processes, 50, 179-211.

Anand, K., \& Kumar, K. (2017). Debt management agency says millennial no worse than predecessors. Malay Mail Online. Retrieved from 
INTERNATIONAL JOURNAL OF ACADEMIC RESEARCH IN BUSINESS AND SOCIAL SCIENCES Vol. 10, No. 2, Feb, 2020, E-ISSN: 2222-6990 @ 2020 HRMARS

http://www.themalaymailonline.com/malaysia/article/debt-management-agency-saysmillennials-no-worse-than-predecessors

Atkinson, A., \& Messy, F. A. (2013). Promoting financial Inclusion through financial education. OECD/ INFE evidence, policies and practices; OECD working papers on finance, insurance and private pensions. No. 34. OECD Publishing. doi :org/10.1787/5k3xz6m88smp-en.

Aydilek, A., \& Aydilek, H. (2019). An optimization model of retiree decisions under recursive utility with housing. Journal of Economics and Finance. doi: 10.1007/s12197-019-09485-5

Baumrind, D. (1980). New direction in socialization research. American Psychologist, 35(7), 639-652.

Brown, M., Grigsby, J., vanderKlaauw, W., Wen, J., \& Zafar, B. (2015). Financial education and the debt behavior of the young. Federal Reserve Bank of New York Staff Reports. Retrieved from https:// www.newyorkfed. org/medialibrary/ media/research/ staffreports/sr634.pdf

Bruhn, M., Ibarra, G. L., \& McKenzie, D. (2014). The minimal impact of large-scale financial education program in Mexico City. Journal of Development Economics, 108, 184-189.

Chen, H., \& Volpe, R. P. (1998). An analysis of personal financial literacy among college students. Financial Services Review, 7(2), 107-128.

Economic Planning Unit. (2016) ELEVENTH. Retrieved from http://rmk11.epu.my/book/ bm/ Rancangan-Malaysia-Kesebelas/Buku RMKe-11.pdf

Economic and Social Commission for Asia and the Pacific (2002). Youth in Malaysia: A review of the youth situation and national policies and programmes. New York : United Nations.

Falahati, L., \& Paim, L. (2012). Experiencing financial problems among university students. An empirical study on the moderating effect of gender. An International Journal, 27(5), 315330.

Fernandes, D., Lynch, J. G. Jr., \& Netemeyer, R. G. (2014). Financial literacy, financial education, and downstream financial behaviors. Management Science, 60 (8), 1861-1883.

Förster, M., Happ, R., \& Walstad, W. B. (2019). Relations between young adults' knowledge and understanding, experiences, and information behavior in personal finance matters. Empirical Research in Vocational Education and Training, 11(1). doi:10.1186/s40461-019-0077-z

Fraczek, B., \& Klimotowicz, M. (2015). Financial literacy and its influence on young customers' decision factor. Journal of Innovation Management, 3(1), 62-84.

Furnham, A., Wilson, E., \& Telford, K. (2012). The meaning of money: The validation of a short money-type measure. Personality and Individual Differences, 52(6), 707-711.

Grimes, P., Rogers, K., \& Smith, R. (2010). High school economic education and access to financial success. Journal of Consumer Affairs, 44(2), 317-335.

Grohmann, A., Kouwenberg, R., \& Menkhoff, L. (2015). Childhood roots of financial literacy. Journal of Economic Psychology, 51, 114-133.

Hastings, J. S., Madrian, B. C., \& Skimmyhorn, W. L. (2013). Financial literacy, financial education, and economic outcomes. Annual Review of Economics, 5(1), 347-373.

Hauff, J. C., Carlander, A., Gärling, T., \& Nicolini, G. (2020). Retirement financial behavior: How important is being financially literate? Journal of Consumer Policy. doi:10.1007/s10603-01909444-x

Hira, T. K., \& Loibl, C. (2005). Understanding the impact of employer-provided financial education on the workplace satisfaction. The Journal of Consumer Affairs, 39, 1. 
INTERNATIONAL JOURNAL OF ACADEMIC RESEARCH IN BUSINESS AND SOCIAL SCIENCES Vol. 10, No. 2, Feb, 2020, E-ISSN: 2222-6990 @ 2020 HRMARS

Hoeve, M., Stamps, G. J. M, Zouwen, M. V. D., Vergeer, M., Jurrius, K., \& Asscher, J. J. (2014). A systematic review of financial debt in adolescents and young adults: Prevalence, correlates and association with crime. Financial debt in Adolescents and Young Adults, 9, 8.

Joo, S., \& Grable, J. E. (2004). An exploratory framework of the determinants of financial satisfaction. Journal of Family and Economic Issues, 25, 25-50.

Kimiyagahlam, F., Safari, M., \& Mansori, S. (2019). Influential behavioral factors on retirement planning behavior: The case of Malaysia. Journal of Financial Counseling and Planning. 3, 2. doi : 10.1891/1052-3073.30.2.244

Koen, V., Asada, H., Nixon, S., Rahuman, M.R.H., \& Arif, A.Z.M. (2017). Malaysia's economic success story and challenges. OECD Economic Department Working Paper, OECD Publishing, Paris. doi.org/10.1787/cf7fddf2-en.

Liu, C. H., \& Tsai, W. S. (2010). The effects of service quality and lifestyle on consumer choice of channel types: The health food industry as an example. African Journal, 4(6), 1023-1039.

Loke, J. Y. (2016). Living beyond one's means: Evidence from Malaysia. International Journal of Social Economics, 43(1), 2-18.

Luksander, A., Béres, D., Huzdik, K., \& Németh, E. (2014). Analysis of the factors that influence the financial literacy of young people studying in higher education. Public Finance Quarterly, 2, 221-241.

Malaysia Youth Index (2015). Institute of Youth Research Malaysia. Retrieved from: http://www.iyres.gov.my/images/indeksbeliamalaysia2015/IBM2015full.pd

Organization for Economic Co-operation and Development (2012). OECD INFE. High level principles on National Strategies for Financial Education. OECD Publishing, Paris.

Organization for Economic Co-operation and Development (2016). Financial education in Europe. Trend and recent development. OECD Publishing, Paris. doi.org/10.1787.9789264254855-en

Perry, V. G., \& Morris, M. D. (2005). Who is in control? The role of self-perception, knowledge, and income in explaining consumer financial behavior. The Journal of Consumer Affairs, 39(2), 299313.

Pham, T. H., Yap, K., \& Dowling, N. A. (2012). The impact of financial management practices and

financial attitudes on the relationship between materialism and compulsive buying. Journal of Economic Psychology, 33, 461-470.

Potrich, A. C. G., Viera, K. M., Coronel, D. A., \& Filho, R. B. (2015). Financial literacy in Southern Brazil: Modeling and invariance between genders. Journal of Behavioral and Experimental Finance, 6, 1-12.

Roberts, J. A., \& Jones, E. (2001). Money attitudes, credit card use, and compulsive buying among American college students. The Journal of Consumer Affairs, 35(21), 213-240.

Shim, S., Barber, B., Card, N., Xiao, \& Serido, J. (2010). Financial socialization of young adults: The role of family, work, and education. Journal of Youth and Adolescence, 39 (12), 1457-1470.

Suwanaphan, S. (2013). Personal financial literacy of academic support employees in Chiang Mai University. Proceeding from Management-Knowledge and International Conference. ZadarCrotia, 1061-1065.

Zaini, M. K., Masrek, M. N., Sani, M. K. J. A., \& Anwar, N. (2018). Theoretical Modeling of Information Security: Organizational Agility Model based on Integrated System Theory and Resource 
INTERNATIONAL JOURNAL OF ACADEMIC RESEARCH IN BUSINESS AND SOCIAL SCIENCES Vol. 10, No. 2, Feb, 2020, E-ISSN: 2222-6990 @ 2020 HRMARS

Based View. International Journal of Academic Research in Progressive Education and Development, 7(3), 390-400.

Bakar, M. Z. A., Bakar, S. A., \& Ayub, S. H. (2020). Financial Education as Moderating Influence in Prudent Financial Management Practices among Malaysian Youth. International Journal of Academic Research in Business and Social Sciences, 10(2), 1-11.

Moissidou, E. (2013). Practices of primary education principals in Greece: Consensus and enforcement. Multilingual Academic Journal of Education and Social Sciences, 1(2), 73-81.

Pernamasari, R. (2018). Implementation of Good Corporate Governance and Voluntary Disclosure Compliance: 100 Compass Index Companies Listed Indonesian Stock Exhange (IDX) 20152016, International Journal of Academic Research in Accounting, Finance and Management Sciences 8 (2): 235-249. 